\title{
$\mathrm{Az}$ arteria carotis interna spontán rekanalizációja
}

\author{
Várnai Blanka dr. ${ }^{1}$ - Simonyi Gábor dr. ${ }^{2}$ \\ Rapcsányi Andrea dr. ${ }^{3}$. Finta Ervin dr. ${ }^{1}$
}

Szent Imre Egyetemi Oktatókórház, ${ }^{1}$ VIP-I Profil, ${ }^{2}$ Anyagcsere Központ, ${ }^{3}$ Radiológiai Osztály, Budapest

\begin{abstract}
Az agyi infarktushoz vezető arteria carotis interna (ICA) elzáródás a leggyakrabban embolia, vagy atherosclerosis talaján kialakult thrombosis miatt jön létre. Az akut ellátást követóen, amennyiben a beteg állapota lehetővé teszi, a beteget otthonába bocsátják, vagy szükség esetén rehabilitációs osztályon folytatják ápolását. Az okklúziót általában véglegesnek tekintik, de a továbbiakban is szükséges a beteg rendszeres duplex ultrahangos (esetenként CT-angiográfos) kontrollvizsgálata. Az irodalmi adatok szerint az esetek egy részében az ICA spontán rekanalizálódhat. A szerzők hazai példán igazolták, hogy az ICA-okklúzió nem minden esetben végleges: egy 67 éves, jobb oldali ICA-okklúziót és következményes stroke-ot elszenvedett, majd spontán rekanalizáció után sikeres endarterectomián átesett férfi esete kapcsán tekintik át az irodalmi adatokat, és adnak javaslatot az ilyen típusú betegek utánkövetésére.

Orv Hetil. 2018; 159(37): 1525-1528.
\end{abstract}

Kulcsszavak: arteria carotis interna, rekanalizáció, endarterectomia, CT-angiográfia

\section{The spontaneous recanalization of the internal carotid artery}

\section{Case report}

The occlusion of the internal carotid artery (ICA) frequently leads to stroke and develops most commonly as a consequence of embolism or atherosclerotic thrombosis. Following acute care, if the patient's general condition makes it possible, the patient is usually emitted from the hospital or, if necessary, his treatment continues in the rehabilitation department. The occlusion is generally considered irreversible, but a regular duplex ultrasonographic (sometimes CT angiographic) check of the patient is required. According to recent literature, spontaneous recanalization of the ICA may occur occasionally. The authors demonstrated by evaluating a local case that ICA occlusion is not necessarily permanent: through a case of a 67 -year-old man, who suffered a right ICA occlusion, subsequent ichaemic stroke, then spontaneous recanalization of the occlusion allowing a successful endarterectomy later on, they overview the literature and propose appropriate prospective examinations to track patents with similar conditions.

Keywords: internal carotid artery, recanalization, endarterectomy, CT angiography

Várnai B, Simonyi G, Rapcsányi A, Finta E. [The spontaneous recanalization of the internal carotid artery. Case report]. Orv Hetil. 2018; 159(37): 1525-1528.

(Beérkezett: 2018. március 5.; elfogadva: 2018. április 3.)

\section{Rövidítések}

$\mathrm{ACM}=($ arteria cerebri media $)$ középső agyi artéria; CDS = (carotis doppler sonography) nyaki Doppler-ultrahang; CT = (computed tomography) komputertomográfia; CTA $=(\mathrm{CT}$ angiography) komputertomográfiás angiográfia; ICA = (internal carotid artery) arteria carotis interna; $\mathrm{LMWH}=($ low-molecular-weight heparin) kis molekulatömegú heparin
Az agyi infarktus a primer halálokok közé tartozik, és vezető a maradandó neurológiai károsodások létrejöttében is [1]. Két fajtája ismert, a vérzéses és az ischaemiás stroke. Ez utóbbi közel 30\%-ban az arteria carotis elzáródásából fakad [2], aminek mortalitási rátája elérheti az 55\%-ot [3]. Az elzáródás leginkább az arteria carotis interna proximalis részénél történik, általában plakkból 
történő embolisatio vagy szúkület okozta hemodinamikai ok - áramlás csökkenése miatt (esetleges többszörös supraaorticus ág vagy inkomplett Willis-kör esetén). Nagyságrendekkel ritkábban előfordulhat trauma vagy spontán dissectio következtében. Korábban az arteria carotis elzáródást stabil, végleges állapotnak tekintették. Az utóbbi időkben azonban kiderült, hogy az esetek körülbelül 11\%-ában az elzáródott carotis rekanalizálódik [4], így előtérbe kerültek a témával foglalkozó tanulmányok $[5,6]$. A statisztikák szerint spontán rekanalizáció gyakrabban fordul elő trauma, vagy dissectio által okozott okklúzió esetében, mint embolisatiónál [7]. A legtöbb leírt esetben a rekanalizáció az okklúzió után egymásfél hónapon belül következett be [8]. Az ér rekanalizációjának patomechanizmusa egyelőre nem ismert. Jelentőségét két tényező adja. Egyrészt a teljes okklúzió, vagyis a lumen $100 \%$-os stenosisa nem múthető, de a rekanalizáció lehetővé teszi az endarterectomia, vagy a sztentelés elvégzését, ezáltal az agyi keringés helyreállítását [9]. Másrészt veszélyeket rejt magában, mivel a rekanalizáció mellett mindig nagyfokú stenosis marad fent, és ez megnöveli egy következő stroke kockázatát [1].

Az alábbiakban egy hazai példát mutatunk be, amelyben a rekanalizáció detektálását követően a beteg sikeres mütéten esett át, állapota jelentősen javult.

\section{Esetismertetés}

A 67 éves férfi beteg története 2014 júliusában kezdödött, amikor a Szent Imre Egyetemi Oktatókórház Sürgősségi Osztályára szállították bal oldali faciobrachialis gyengeség, azonos oldali végtagi zsibbadás és dysarthria tüneteivel. Családi anamnézisében stroke szerepelt. Kórelőzményében szorongásos depressziót, számos cardiovascularis elváltozást, hypertoniát (1980 óta), akut myocardialis infarctust (2001), multiplex generalizált végtagi obliterativ érbetegséget, hasiaorta- és bal oldali arteria iliaca aneurizmát, valamint hypercholesterinaemiát írtak le. Ez utóbbi megfelelő gyógyszerezéssel a megfigyelés időpontjában rendezett volt. 2013 decemberében carotis-Doppler-ultrahangvizsgálat során a bal oldali arteria carotis interna (ICA) 50\%-os, a jobb oldali ICA 65-70\%os szúkületére derült fény. A 2014. júliusi tünetek koponya-CT-vizsgálatot indikáltak, amely a jobb arteria cerebri media (ACM) ellátási területének megfelelően akut korai ischaemiának megfelelő elváltozást igazolt, emellett szubakut történésre utaló jeleket is találtak ( $1 / A$ ábra). A nyaki CT-angiográfia (CTA) a jobb oldali ICA elzáródását mutatta ki az akut ACM-ischaemia okaként. Ugyanakkor a bal oldali ICA is $60 \%$-os szúkületet mutatott $(1 / B$ ábra). Mindkét ICA intracranialis szakaszán meszesedés látszódott, mely szúküuletet okozott. A Willis-kör variációs, de komplett volt. Az arteria vertebralisok áramlása anterográd irányú és normális sebességű volt.

A diagnózis alapján a beteget a kórház Neurointenzív Osztályára helyezték. A szubakut ischaemiás előzmény a szisztémás thrombolysist kontraindikálta, így a páciensnek klopidogrél (tabl. $75 \mathrm{mg}$ ) és kis molekulatömegú heparin (LMWH) terápiát $(0,3 \mathrm{ml}$ enoxaparin inj. sc.) állítottak be. Emellett folytatták régebbi gyógyszereit, a hypercholesterinaemiára szedett rozuvasztatin (tabl. 40 mg) és a szorongásos depressziójára felírt alprazolám (tabl. $2 \times 0,25 \mathrm{mg}$ ) adagolását. A beteg állapota 24 óra elteltével intenzív ellátást már nem igényelt, ezért a továbbiakban kezelését a kórház Stroke Profilja vette át,

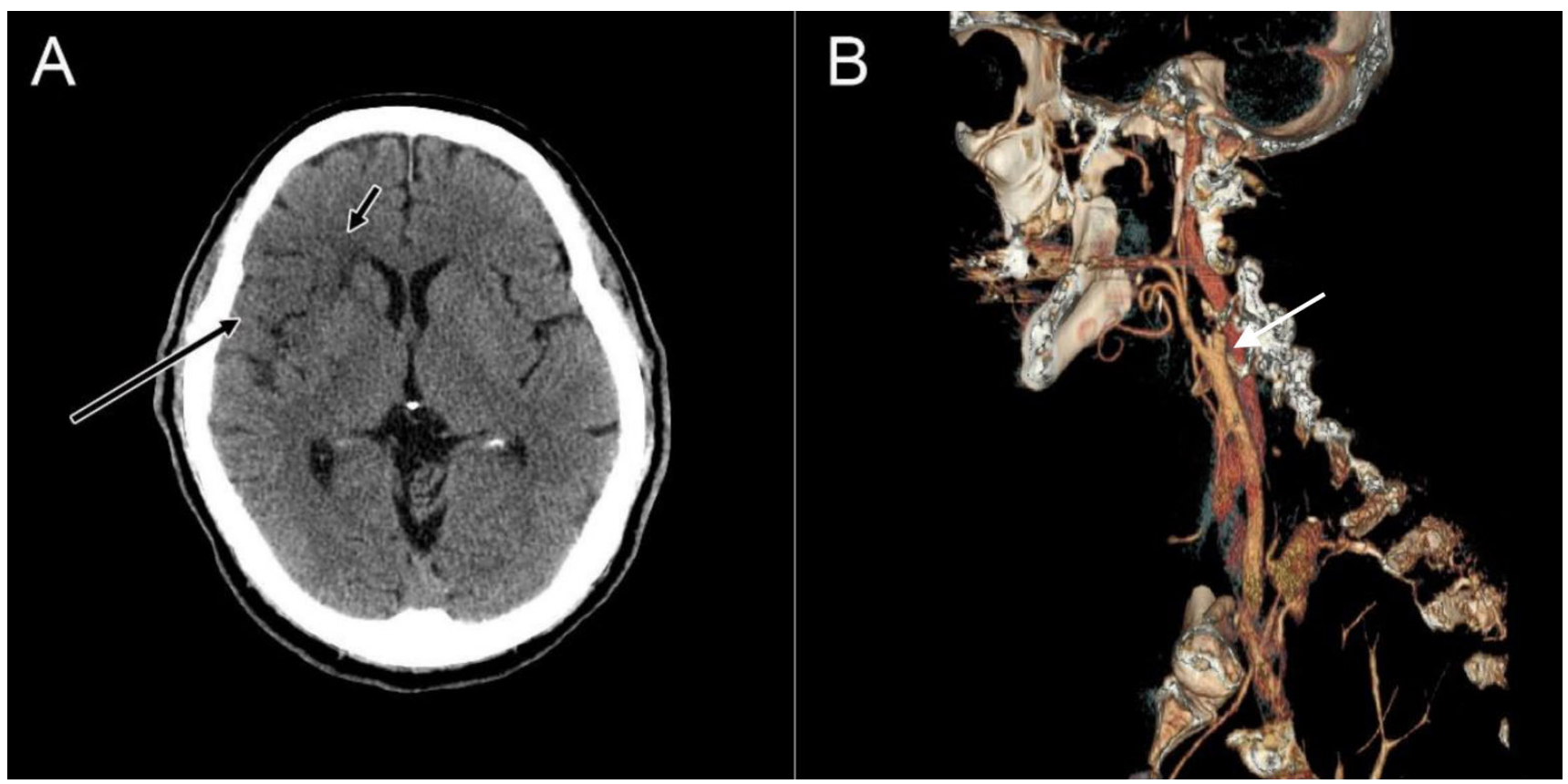

1. ábra $\quad$ A) Koponya-CT, amelyen a jobb arteria cerebri media (ACM) ellátási területének megfelelően akut korai ischaemiás elváltozás ábrázolódik (nyilak). B) Nyaki CT-angiográfia (CTA), amelyen a jobb oldali arteria carotis interna (ICA) okklúziója (nyíl) látható 


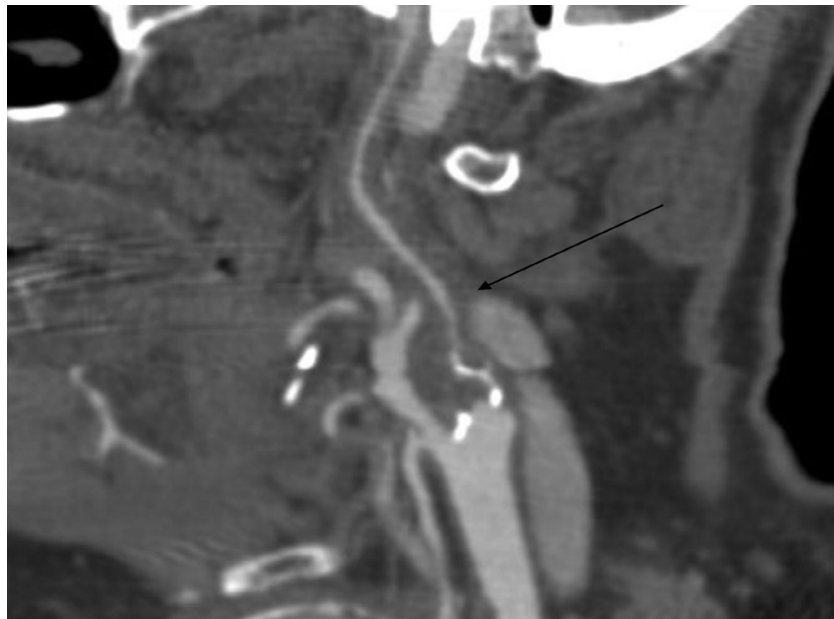

2. ábra $\mid$ Éves kontroll-carotis-CTA, amelyen a jobb oldali ICA rekanalizációja látható

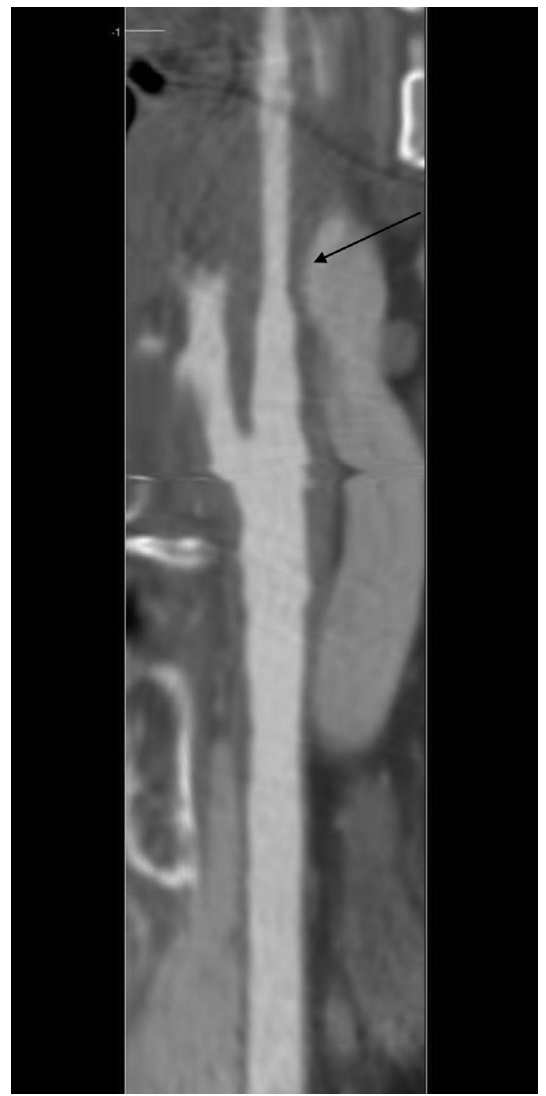

3. ábra 2017. évi CTA, amelyen a jobb oldali ICA restenosisa nem lát-
ható

ahol kiegészítő terápiaként piracetámtartalmú infúziókat kapott. Egy hét múlva az LMWH-injekciót elhagyták, és a beteget az egyéb gyógyszerek folytatása mellett tünetmentesen otthonába bocsátották. 2014. szeptemberben CT-angiográfos kontrollvizsgálat alapján az érsebész változatlan állapotot véleményezett, csakúgy, mint a 2015. januári érsebészeti kontroll a friss duplex ultrahang (UH)-eredménnyel. Először a 2015. áprilisban készült nyaki Doppler-ultrahang (CDS) vetette fel a jobb oldali
ICA okklúziójának megszúnését: 90\%-os stenosisát írták le, a bal oldali változatlan állapota mellett. A jobb oldali rekanalizáció létrejöttét carotis-CT-angiográfiával (CTA) is alátámasztották (2. ábra). Érsebész-konzílium a gyógyszeres kezelés folytatását javasolta, véleményük szerint a distalis szakasz igen gracilis volta miatt mütét nem jött szóba. A 2015 októberében zajlott érsebészkonzílium is úgy foglalt állást, hogy „A jobb oldali subtotalis stenosis (rekanalizálódott elzáródás) nem operálandó”. Fél év múlva javasoltak kontroll képalkotó vizsgálatot és eredményével érsebészeti ellenőrzést. Az ennek megfelelően, a stroke után két évvel, 2016 májusában készült kontroll-CDS a rekanalizálódott ér szúkületének progresszióját véleményezte. Az UH alapján a jobb oldali ICA 95\%-os stenosisát írta le, ezt az egy hónap múlva végzett koponya-CTA is megerősítette. Emiatt a páciens saját szervezésében másutt történt érsebészeti vizsgálatot követően 2016 novemberében az Érsebészeti Klinikán az adott oldalon sikeres vascularis intervenciós mútétet, carotiseverziós endarterectomiát hajtottak végre. A 2017. januári carotis-UH- és -CTA(3. ábra) vizsgálaton jobb oldali restenosis nem látszott.

\section{Következtetések}

Az elzáródott carotis spontán rekanalizációja ritkán történik meg, de nem példa nélküli. Shchanitsyn és mtsai 1045 eset adatait elemezték a PubMed-en 1958 és 2014 között megjelent cikkek alapján, és 3,6\%-ban találtak spontán rekanalizációt [8]. Más vélemények szerint viszont előfordulása akár 10\%-ra is tehető $[10,11]$. Érdekes módon a rekanalizáció javarészt 65 év körüli férfiak között fordul elő [8]. A jelen eset az életkor és a nem szempontjából a leggyakoribb kategóriába tartozik.

Az okklúziótól a rekanalizációig eltelt időintervallum a statisztikák szerint változó. A rekanalizáció bekövetkeztének pontos időpontja nehezen becsülhető, mivel az egyes esetekben a képalkotó kontrollvizsgálatok gyakorisága eltér. Megtörténhet néhány hónapon belül [12], de akár évek alatt is [13]. Az átlagos időtartam körülbelül 3 év [11, 13]. A lassan kifejlődő spontán rekanalizáció főleg a dissectio és embolia okozta okklúziók esetében alakul ki, ezzel szemben korai rekanalizáció jobbára az atherosclerosis miatt kialakult thrombosis okozta okklúziót követően jön létre [8]. Esetünkben az okklúziót atherosclerosis okozta, a rekanalizáció észleléséig eltelt idő 14 hónap volt, de nem zárható ki biztonsággal, hogy már korábban létrejött.

A rekanalizáció valószínűségét számos tényező befolyásolja. A bal oldalon nagyobb valószínúséggel történik meg, mint a jobb oldalon. Érdekesség, hogy stroke is ezen az oldalon éri gyakrabban a betegeket. Összefügg az elzáródásos plakk méretével, összetételével, valamint a kollaterálisér-hálózat fejlettségével is. Minél nagyobb a plakk, annál kisebb a rekanalizáció valószínûsége. Az öszszetétel szempontjából a fibrintartalom meghatározó fontosságú, a fibringazdag embolusok okozta okklúziók 
ugyanis könnyebben rekanalizálódnak. A rekanalizáció mechanizmusa egyelőre ismeretlen. Elképzelhető, hogy az intravascularis thrombus spontán feloldódik, vagy distalis irányba elmozdul. Létrejöhet azonban átmeneti vasospasmus megszűnése miatt, vagy okozhatja az érfal ideiglenes ödémájának eltünése is [8]. Az általunk talált esetben a rekanalizáció utáni évben az átáramlás újból romlott, megindult a reokklúzió. Szerencsére a betegnél még időben endarterectomiát hajtottak végre, ami teljes reperfúzióhoz vezetett. Esetünk azt bizonyítja, hogy bár a spontán rekanalizáció ritka, a beteg szempontjából nagy jelentőségű az időben történő kimutatása. A neurológiai, radiológiai és érsebészeti irányelvek egyértelmű követést javasolnak a supraaorticus ágak érintettsége esetén. A CT-, illetve MR-angiográfia könnyen hozzáférhető, kevésbé invazív eljárás, melyek segítségével jól diagnosztizálható az elváltozás. Ezenkívül adott esetben a Doppler-ultrahangvizsgálat is megfelelő információt nyújthat. A digitális szubtrakciós arteriográfia hátránya, hogy invazív, és az esetek 5\%-ában komplikációk (akár stroke is) lépnek fel [14]. Meg kell említeni, hogy a szisztematikusan áttekintett magyar és külföldi guideline-ok sajnos nem tartalmaznak egyértelmű iránymutatást az okklúzió után végzendő képalkotó vizsgálatok milyenségére és gyakoriságára [15]. Fontos lehet a carotisokklúzióval rendelkező betegek esetében a rekanalizáció felismerését követően az azonnali helyreállító mútét elvégzése [12]. Az egyénre szabott döntésben azonban elengedhetetlen a beteg általános állapotának, rizikófaktorainak, neurológiai statusának, a várható életkilátásának, a carotis morfológiájának és az intracranialis keringésnek az együttes értékelése multidiszciplináris megbeszélés keretében, mivel egy rosszul indikált beavatkozás fatális stroke-hoz is vezethet. Összefoglalva elmondhatjuk, hogy a spontán carotisrekanalizáció felismerése és megfelelő kezelése a beteg hosszú távú egészségi állapota szempontjából meghatározó lehet. Prospektív vizsgálatok lennének szükségesek az előfordulás gyakorisága, a terápiás intervenció módjai és az azt követő életkilátások összefüggéseinek feltárásához, melyek alapján a carotisrekanalizáció jelensége mind a guidelineokban, mind a klinikai gyakorlatban megkaphatná kellő helyét és súlyát.

Anyagi támogatás: A szerzők a közlemény megírása, illetve a kapcsolódó kutatómunka során anyagi támogatásban nem részesültek.

Szerzôi munkamegosztás: V. B., F. E.: A vizsgálat hipotézisének kidolgozása, az adatgyüjtés megtervezése, a kézirat megszövegezése. R. A.: A képalkotó vizsgálatok elemzése, az adatok feldolgozása, a kézirat megszövegezése. S. G.: A vizsgálat hipotézisének kidolgozása, a kézirat megszövegezése. A cikk végleges változatát valamennyi szerző elolvasta és jóváhagyta.

Érdekeltségek: A szerzőknek nincsenek érdekeltségeik.

\section{Köszönetnyilvánítás}

Köszönet illeti $d r$. Banga Péter klinikai szakorvost (Semmelweis Egyetem, Ér- és Szívsebészeti Klinka) az everziós endarterectomia elvégzéséért és a beteg további érsebészeti gondozásáért, valamint Csányi Edina szonográfust a rekanalizáció, illetve az azt követő újbóli okklúzió veszélyének felismeréséért.

\section{Irodalom}

[1] Warlow C. Disorders of the cerebral circulation. In: Walton J. (ed.) Brain's diseases of the nervous system. Oxford University Press, Oxford, 1993; pp. 197-210.

[2] Michel P, Odier C, Rutgers M, et al. The Acute STroke Registry and Analysis of Lausanne (ASTRAL): design and baseline analysis of an ischemic stroke registry including acute multimodal imaging. Stroke 2010; 41: 2491-2498.

[3] Klonaris C, Alexandrou A, Katsargyris A, et al. Late spontaneous recanalization of acute internal carotid artery occlusion. J Vasc Surg. 2006; 43: 844-847.

[4] Cheema S, Clarke-Moloney M, Kavanagh EG, et al. Natural history and clinical outcome of patients with documented carotid artery occlusion. Ir J Med Sci. 2007; 176: 289-291.

[5] Verlato F, Camporese G, Bernardi E, et al. Clinical outcome of patients with internal carotid artery occlusion: a prospective follow-up study. J Vasc Surg. 2000; 32: 293-298.

[6] Nguyen-Huynh MN, Lev MH, Rordorf G. Spontaneous recanalization of internal carotid artery occlusion. Stroke 2003; 34: 1032-1034.

[7] Parenti G, Marconi F, Canapicchi R, et al. Spontaneous recanalization of carotid artery occlusion following non traumatic dissection. Ital J Neurol Sci. 1989; 10: 361-367.

[8] Shchanitsyn IN, Maksyushina TD, Titova YI, et al. Spontaneous recanalization of chronic occlusion of the internal carotid artery. Angiol Sosud Khir. 2015; 21: 124-135.

[9] Shah QA. Spontaneous recanalization after complete occlusion of the common carotid artery with subsequent embolic ischemic stroke. J Vasc Interv Neurol. 2009; 2: 147-151.

[10] Szabo K, Kern R, Gass A, et al. Early spontaneous recanalization following acute carotid occlusion. J Neuroimaging 2008; 18 : 148-153.

[11] Morris-Stiff G, Teli M, Khan PY, et al. Internal carotid artery occlusion: its natural history including recanalization and subsequent neurological events. Vasc Endovascular Surg. 2013; 47: 603-607.

[12] Som S, Schanzer B. Spontaneous recanalization of complete internal carotid artery: a clinical reminder. J Surg Tech Case Rep. 2010; 2: 73-74.

[13] Camporese G, Labropoulos N, Verlato F, et al. Benign outcome of objectively proven spontaneous recanalization of internal carotid artery occlusion. J Vasc Surg. 2011; 53: 323-329.

[14] Warnock NG, Gandhi MR, Bergvall U, et al. Complications of intraarterial digital subtraction angiography in patients investigated for cerebral vascular disease. Br J Radiol. 1993; 66: 855858.

[15] Abbott AL, Paraskevas KI, Kakkos SK, et al. Systematic review of guidelines for the management of asymptomatic and symptomatic carotid stenosis. Stroke 2015; 46: 3288-3301.

(Várnai Blanka dr., Budapest, Tétényi út 12-16., 1115 e-mail: varnaiblanka@hotmail.com) 